\title{
9: $114983651-115244477$
}

National Cancer Institute

\section{Source}

National Cancer Institute. 9: 114983651-115244477. NCI Thesaurus. Code C42126.

Physical location of DEC1_Gene 